\title{
Tackling economic exclusion through social business models: a typology
}

\author{
Caroline Gauthier, Genevieve Shanahan, Thibault Daudigeos, Adélie Ranville \\ \& Pascal Dey
}

To cite this article: Caroline Gauthier, Genevieve Shanahan, Thibault Daudigeos, Adélie Ranville \& Pascal Dey (2020): Tackling economic exclusion through social business models: a typology, International Review of Applied Economics, DOI: 10.1080/02692171.2019.1707785

To link to this article: https://doi.org/10.1080/02692171.2019.1707785

\section{曲 Published online: 19 Jan 2020.}

\section{Submit your article to this journal ¿}

Џ Article views: 12

Q View related articles

View Crossmark data [ᄌ 


\title{
Tackling economic exclusion through social business models: a typology
}

\author{
Caroline Gauthier (iD) ${ }^{\mathrm{a}, \mathrm{b}}$, Genevieve Shanahanc, Thibault Daudigeos ${ }^{c}$, Adélie Ranville \\ and Pascal Deyc \\ aManagement of Technology and Strategy, Grenoble Ecole de Management, Univ Grenoble Alpes ComUE,

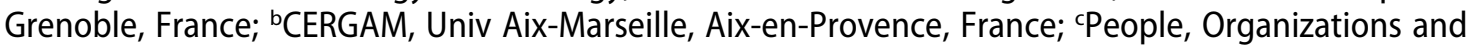 \\ Society, Grenoble Ecole de Management, Univ Grenoble Alpes ComUE, Grenoble, France
}

\begin{abstract}
This article contributes to on-going research on social business models by establishing a link with arguably one of the most salient global challenges we are confronted with today: economic exclusion. We conceive of economic exclusion broadly as a lack of access to salaried employment, finance, or essential goods and services. Addressing how and to what extent social business models can alleviate economic exclusion, we first review and synthesize various bodies of literature on grand challenges and social business models to unpack the constitutive factors of economic exclusion and the constraints social businesses face in their attempts to alleviate them. Based on these insights, and inspired by former works, we draw up a typology of 12 ideal-type social business models. In doing so, we illustrate how each model operates, based on the specific configuration of business model elements required to overcome the relevant barriers underpinning economic exclusion. The main contribution the paper makes is to advance a typology of ideal-type social business models covering the diverse constraints pertaining to economic exclusion. In concluding, we reflect on this contribution, its limitations and avenues for future research.
\end{abstract}

\section{ARTICLE HISTORY}

Received 21 December 2018 Accepted 11 November 2019

\section{KEYWORDS}

Social business model; economic exclusion; grand challenge; social business

\section{JEL CLASSIFICATION} L26; 035

\section{Introduction: linking grand challenges and business model approaches}

Management scholars have increasingly called for research that is practically relevant and not 'just' scientifically rigorous (Gulati 2007; Tsui 2019). Attempts to bridge the notorious divide between theory and practice have resulted in variegated initiatives, such as research aspiring to rethink the 'purpose of the corporation' (Freeman and Ginena 2015; Veldman and Willmott 2013), research that elaborates the political role of business in society (Scherer and Palazzo 2011), and pleas for interventionist (Steyaert 2011), emancipatory (Spicer, Alvesson, and Kärreman 2009) or impact-focused research (Margolis and Walsh 2003). What unites these disparate endeavors are two realizations. First, that humanity is confronted with a host of grand challenges, including climate change, social exclusion and persistent poverty, to name but a few (for a comprehensive list of global 
grand challenges see the 17 universal Sustainable Development Goals [SDGs] of the United Nations). Second, that business approaches, as well as management and organization theory more broadly, are well placed to contribute to the resolution or mitigation of these grand challenges (Ferraro, Etzion, and Gehman 2015; George et al. 2016).

Recent pleas to deploy business approaches to tackle grand challenges have had a profound influence on research on business models, as is evident from the surge of research on sustainable and social business models ${ }^{1}$ (Yunus, Moingeon, and Lehmann-Ortega 2010; Bocken et al. 2014; Dentchev et al. 2018; Spieth et al. 2018), the latter of which represent the focus of our investigation. The business model concept offers a language for describing the value configuration of a given business by focusing on 'the design or architecture of the value creation, delivery, and capture mechanisms it employs' (Teece 2010, 172). Yet where traditional business models are organized to maximize value capture (economic value produced for the focal enterprise through revenue streams from sold services or goods, or financial streams from various stakeholders; Hlady-Rispal and Servantie 2018), social business models rather focus on the simultaneous pursuit of economic and social value (Sinkovics, Sikovics, and Yamin 2014; Saebi, Foss, and Linder 2019). Although no authoritative definition exists today, social value creation is commonly conceived of as the process of transferring value that could potentially be captured by the focal enterprise to the various stakeholders - notably target beneficiaries - who are part of the overarching value creation ecosystem. Understood in this way, enterprises adopting a social business model approach can be thought of as social businesses that are defined by their willingness to sacrifice some value capture (economic value created for the focal enterprise) in order to increase social value for its various constituents, including society at large (which can be understood as positive externalities, Santos 2012). Value creation pursued by social businesses thus pays greater heed to the role and interests of the focal enterprises' core stakeholders, not least its beneficiaries (Le Ber and Branzei 2010). The corollary, then, is that social business models will mainly be used by enterprises that intentionally - courtesy of their explicit social mission - aim to solve social problems. That is, in contrast to profit-driven business actors who might incidentally engage in pro-social activities for primarily instrumental reasons (economic bottom line) (Calás, Smircich, and Bourne 2009), positive societal change is the primary reason why social businesses make use of social business models (Santos 2012; Stephan et al. 2016). As an illustration, the primary aim of work integration social enterprises is not to maximize economic value (profit), but rather to create social alongside economic value by employing people excluded from the regular job market (Battilana et al. 2015). On the other side, social businesses can be distinguished from charities on the basis of the latter's pure focus on social value creation to the exclusion of value capture (Yunus, Moingeon, and Lehmann-Ortega 2010; Wilson and Post 2013). While under the definition advanced here, social businesses must sacrifice some value capture in favor of social value creation, charities are typically understood as entirely not-for-profit, and thus sacrifice all value capture. To support their operations, charities rely on, for instance, donations and grants (Sinkovics, Sikovics, and Yamin 2014). Where charities engage in economic value capture to support their social value creation efforts, we would say that they count as social businesses under this definition. For such social businesses, value capture leading to profit is merely a necessary means to achieve sustainability in pursuit of the enterprise's social purpose. Since profit is not an end in itself, there is no a priori reason for social businesses to maximize it. 
Despite the undeniable significance of extant research on social business models, what is less readily registered is that such models are always employed in particular contexts, with the aim of solving specific problems through the creation of value for particular subjects, groups or organizations (Le Ber and Branzei 2010; Wirtz et al. 2016). Consequently, what we know about social business models is limited to general insights about the value creation dynamics of social businesses. What is missing in existing research, with a few notable exceptions (e.g. Barth, Ulvenblad, and Ulvenblad 2017), is a systematic analysis of the relationship between social business models and specific grand challenges. The current paper addresses this gap by providing one challenge-specific view on social business models, taking a closer look at economic exclusion. We focus on economic exclusion as it is one of the most wicked problems humanity is confronted with today (UNDP 2011). Focusing on a particular grand challenge, we argue, offers fertile ground for expanding extant research on social business models by increasing the contextual awareness, granularity and practical 'use value' of social business model approaches. Drawing on and expanding this research on (social) business models (Zott and Amit 2007, 2010; Zott, Amit, and Massa 2011; BadenFuller and Mangematin 2013; Doganova and Eyquem-Renault 2009; Osterwalder 2004), we particularly aim to contribute to the literature by uncovering tensions and complementarities between business model elements (Saebi, Foss, and Linder 2019) in the particular context of economic exclusion.

The remainder of this paper proceeds in two broad steps. First, we identify the main barriers preventing people from participating in the economic process - as consumers, employees or entrepreneurs - and we reflect on the main constraints social businesses face while trying to address these barriers. In the second step, we expand the discussion by linking our tentative considerations with the rapidly growing field of social business model scholarship in order to identify ideal-type business models that social businesses can leverage to tackle the different underlying constraints of economic exclusion. We conclude by exploring the theoretical contributions and limitations of our study, and identify potential areas for prospective research.

\section{Economic exclusion and constraints for social businesses}

Economic exclusion is arguably one of the most salient grand challenges facing us today (Prahalad and Hammond 2002; Whelan and Maitre 2005). Economic exclusion constitutes a multifaceted and diverse phenomenon comprising various barriers, including 'limits to people's access to the labor, financial and housing markets, as well as to essential goods and services' (UNDP 2011, 16). At the macro-economic level, economic exclusion is considered a major hindrance to growth and wealth creation (Wheatley 2007). At the individual level, economic exclusion in the form of lacking access to essential goods, services, income and/or entrepreneurial opportunities prevents people from achieving the status of economic citizens, with attendant secondary negative effects (McKee-Ryan et al. 2005). For instance, people without proper access to retailing infrastructure tend to be excluded from participating in society more generally (Battilana et al. 2015; Amis, Munir, and Mair 2017; Cholez et al. 2012; Wrigley et al. 2002).

Several interrelated factors are constitutive of economic exclusion. On the consumption side, the literature identifies a lack of purchasing power, lack of willingness to pay for essential goods and services ${ }^{2}$ and a lack of access to essential goods and services as the 
three core barriers to economic inclusion. A lack of purchasing power designates a situation in which an individual is willing to purchase a given item, but lacks the financial resources to do so. Alternatively framed, we can think of this barrier as a market failure to serve the specific needs of marginalized consumers by offering items at a price that is affordable to them. This failure is critical to understanding the consumption patterns of the economically excluded (Dror, Radermacher, and Koren 2007; Viswanathan and Sridharan 2012). Additionally, consumers' unwillingness to pay for essential goods and services can act as a barrier to economic inclusion. The goods and services essential for securing fundamental capabilities are not always obvious, and since consumer perceptions are socially constructed and induced, education plays an important role in shaping willingness to pay for such products and services. In these cases, economic exclusion can result from persistent prejudices, lack of awareness or stigma attached to certain products or services, regardless of financial means. Overcoming such barriers requires that economically excluded populations take a positive view of essential goods and services, thus strengthening their willingness to engage. Finally, economic exclusion can result from a lack of access to essential goods and services not reducible to mere lack of resources. These barriers to consumption for marginalized groups can involve geographic isolation (distance from markets where essential goods and services are traded; Yunus, Moingeon, and Lehmann-Ortega 2010), regulatory impediments (Chaurey et al. 2012), and other complex social constraints (Bloom 2009; Weidner, Rosa, and Viswanathan 2010).

On the production side, understood primarily in terms of employment and entrepreneurial opportunity, the lack of resources, lack of willingness and lack of access categories similarly apply. In this respect, the literature highlights a lack of valuable skills (which we can understand as a type of resource; UNDP 2011), undervaluation of skills leading to a lack of willingness to engage in the job market (Sirkeci et al. 2018), and a variety of technical and social impediments to access to financial services and jobs (Hodge et al. 2002; Sundaram et al. 2015).

In the remainder of this paper, we use these three categories of barriers to economic inclusion to conceptualize ideal-type business models: a) a lack of resources (finance or skills), b) a lack of willingness to engage (in consumption, employment or entrepreneurial activity), and c) a lack of access (to essential goods, services, jobs or entrepreneurial opportunities). Of course, these barriers are intimately interrelated (for instance, where a lack of access to essential goods precipitates a community's economic marginalization, which in turn curbs the community's inability to engage in consumption). Nevertheless, we contend that the distinction of the three barriers does offer analytical purchase on the configuration of different business model architectures.

The literature tends to show that although traditional, profit-driven businesses can instigate transformative social impacts (Calás, Smircich, and Bourne 2009), potential conflicts between commercial and social objectives limit such enterprises' commitment to social value creation (McDonald 2007). While traditional businesses thus only engage with grand challenges where a strong economic incentive exists (Prahalad and Hammond 2002), social businesses have a key role to play in providing viable solutions to economic exclusion under conditions that might not necessarily yield maximal profits. According to the definition we adopt here, the constraint of weak economic incentives does not prevent social businesses from engaging with barriers related to economic 
exclusion. Nevertheless, the challenge remains for social businesses to establish a financially sustainable means of social value creation which effectively addresses the low potential for value capture (Santos 2012, 338). Given this situation, it is exigent to investigate how business models that allow social businesses to foster economic inclusion both create value for their various stakeholders and capture value.

\section{Existing typologies}

Sanchez and Ricart (2010) suggest that social business models for low-income markets can be understood as falling into one of two categories: isolated and interactive business models. The 'isolated' model involves increasing efficiency in the value creation process so as to reduce costs and 'fix the price below the consumer's willingness [and ability] to pay' (148). These models are labeled 'isolated' because the business in question acts alone and draws on its own internal resources to create value. Often this model corresponds to 'base-of-the-pyramid' strategies, where the business in question pursues growth by entering low-income markets with adapted and optimized products (145). The interactive' model, by contrast, involves cooperation and partnership with external stakeholders and the development of 'relational capabilities' of the different actors involved (147). The interactive model increases economically excluded customers' willingness to pay 'by enhancing the value created for and the capacity to pay of customers,' often through 'removing the barriers that prevent [...] socioeconomic development' (148). This model thus does not solely conceive of target beneficiaries as recipients of the business' products or services, but also as value producing actors in their own right.

Sanchez and Ricart (2010) typology draws an important distinction between value creation that relies exclusively on the firm's own capabilities, and that which draws on the wider ecosystem of actors. Yet this focus on how social value is created for the beneficiaries is accompanied by relative neglect of how businesses capture economic value. The balance between the economic and social mission is key for the financial sustainability of a social business, and therefore value capture merits special attention in the construction of social business models. Since there are many possible value capture configurations, not all social business models are accounted for in the Sanchez and Ricart typology.

Addressing some of these concerns, Saebi, Foss, and Linder (2019) have proposed a more nuanced two-by-two typology. First, they categorize social enterprises according to whether their social mission is 'for beneficiaries', that is, conceiving of beneficiaries as passive receivers of certain goods or services (read consumers), or 'with beneficiaries', where the target group adopts an active role in the value creation process. Second, the authors distinguish business models that rely on income from the target beneficiaries themselves ('integrated') from those that court other customers to cross-subsidize the consumption of the target population ('differentiated').

The 'one-sided value model' here identified broadly corresponds with the isolated model discussed by Sanchez and Ricart (2010). In such cases, social businesses 'find innovative ways to minimize the cost of production and delivery to sell affordable goods or services to those in need' (Saebi, Foss, and Linder 2019, 76). Design and value chain innovations, for instance, can be used to increase efficiency and pass savings on to consumers. Rethinking target consumers' needs also allows for price innovations that make the product or service 
more affordable. For instance, where ownership of a good is not necessary, sharing or payper-use of that good can be an effective way to increase financial accessibility (e.g. the payper-minute telephone rental approach employed by Grameen Phone/Telenor; Yunus, Moingeon, and Lehmann-Ortega 2010). This model involves just one integrated value proposition targeted to beneficiaries as paying customers. Alternatively, the cost of the product or service for the target beneficiary can be offset with revenues from goods or services offered to more affluent customers. Such 'two-sided value models' are differentiated as they offer separate value propositions to different stakeholders - target beneficiaries and affluent customers - to facilitate 'cross-financing'. An exemplary case in this regard is the so-called 'Robinhood' strategy whereby higher-income customers pay a higher price for a given item compared to their lower-income counterparts. The surplus income from the higher-income customers is then used to lower the costs for the target beneficiaries. In a similar vein, 'freemium' strategies create revenues from the full-feature product or service which in turn allow the business to offer a more limited version free of charge (Gassmann, Frankenberger, and Csik 2014).

The 'with beneficiaries' dimension can also be subdivided into differentiated and integrated forms. The former is labeled the 'market-oriented work model', whereby target beneficiaries are employed to produce products and services which are sold to paying customers, thereby providing separate value propositions for the target beneficiaries and the paying customers. The literature on social entrepreneurship, and on work integration social enterprises more specifically (Battilana et al. 2015; Defourny and Nyssens 2017), has been instrumental in creating awareness about this approach, shedding light on how commercial mechanisms can be used to foster labor market integration through the creation of employment and training opportunities. Conversely, the integrated value proposition is labeled the 'social-oriented work model' by Saebi and colleagues. Here, beneficiaries simultaneously act as producers and consumers. This business model includes social businesses that employ a subset of the target beneficiary population, and also those that reduce the cost to target beneficiaries as consumers by involving these consumers in the value creation process. The second-generation literature on the bottom-of-the-pyramid labels this latter case as 'inclusive value chains' connecting (multinational) corporations and poor communities as a promising vehicle for economic inclusion (Austin et al. 2007; Marquez, Reficco, and Berger 2010). ${ }^{3}$ While 'with beneficiaries' models can be understood as attempts to increase the purchasing power of beneficiaries, this end can also be achieved by supporting target beneficiaries' entrepreneurial endeavors, whether through microfinance (e.g. Grameen Bank, Yunus, Moingeon, and Lehmann-Ortega 2010; see also Battilana and Dorado 2010; Newman, Schwarz, and Ahlstrom 2017), disintermediation (e.g. Equal Exchange, Wilson and Post 2013), or other facilitation measures such as training or networking.

In the next section, we further elaborate on and expand Saebi, Foss, and Linder (2019) framework to propose a typology of social business models to address economic exclusion.

\section{A typology of ideal-type business models to tackle economic exclusion}

Saebi, Foss, and Linder (2019) typology is especially helpful in distinguishing important dimensions of social business models. However, we want to propose that paying more 
detailed attention to the specific barriers to target beneficiaries' economic inclusion can enhance the precision of the model. We thus contend that the challenge of economic exclusion is not merely a question of target beneficiaries' lacking resources, but also of lacking access and deterrents to engagement (including cultural and psychological barriers). Table 1 distinguishes model with beneficiaries participating to value creation process to model where they are solely recipients.

Describing value creation and value capture business model elements for each type of model outlined in Table 2 helps us conceptualize the trade-offs social businesses face when addressing specific aspects of economic exclusion (lack of resources, lack of

Table 1. A typology of social entrepreneurship (reproduced from Saebi, Foss, and Linder (2019)).

\begin{tabular}{lcc}
\hline & $\begin{array}{c}\text { For beneficiaries } \\
\text { (Beneficiaries are solely } \\
\text { recipients) }\end{array}$ & $\begin{array}{c}\text { With beneficiaries } \\
\text { (Beneficiaries are part of value creation } \\
\text { process) }\end{array}$ \\
\hline $\begin{array}{l}\text { Differentiated } \\
\text { (Commercial revenue cross-subsidizes } \\
\text { social mission) } \\
\begin{array}{l}\text { Integrated } \\
\text { (Beneficiaries are paying customers) }\end{array}\end{array}$ & Two-sided value model & Market-oriented work model \\
\hline
\end{tabular}

Table 2. Typology of 12 ideal-type business models.

\begin{tabular}{|c|c|c|}
\hline & Value creation excludes beneficiaries & Value creation involves beneficiaries \\
\hline $\begin{array}{l}\text { Value proposition and value } \\
\text { capture target beneficiaries }\end{array}$ & One-sided value model & Co-production model \\
\hline Resources & $\begin{array}{l}\text { AFFORDABLE PROVIDER - Make the } \\
\text { product/service affordable by } \\
\text { increasing efficiency or changing the } \\
\text { pricing model. }\end{array}$ & $\begin{array}{l}\text { DIY ENABLER - Make the product/service } \\
\text { affordable by including beneficiaries } \\
\text { in value creation. }\end{array}$ \\
\hline Willingness to engage & $\begin{array}{l}\text { DESIGNER - Make the product/service } \\
\text { attractive by removing aesthetic, } \\
\text { cultural, psychological barriers to } \\
\text { consumption (e.g. by improving } \\
\text { design or marketing, education). }\end{array}$ & $\begin{array}{l}\text { CO-CREATOR - Make the product/service } \\
\text { attractive by removing aesthetic, } \\
\text { cultural, social, psychological barriers } \\
\text { to consumption by co-designing the } \\
\text { product/service with the target } \\
\text { beneficiaries. }\end{array}$ \\
\hline Access & $\begin{array}{l}\text { MARKET EXPANDER - Make the product/ } \\
\text { service accessible by removing } \\
\text { technical or social barriers to } \\
\text { consumption. }\end{array}$ & $\begin{array}{l}\text { FACILITATOR - Make entrepreneurial and } \\
\text { career supports accessible to target } \\
\text { beneficiaries through innovative } \\
\text { pricing and risk-management } \\
\text { strategies. }\end{array}$ \\
\hline $\begin{array}{l}\text { Value proposition targets } \\
\text { beneficiaries and third } \\
\text { parties; value capture } \\
\text { targets third parties }\end{array}$ & Two-sided value model & Work integration model \\
\hline Resources & $\begin{array}{l}\text { MATCHER - Make the product/service } \\
\text { affordable by subsidizing the } \\
\text { consumption of beneficiaries with } \\
\text { product/service targeted to third } \\
\text { parties. }\end{array}$ & $\begin{array}{l}\text { JOB PROVIDER - Increase beneficiaries' } \\
\text { income by providing jobs, financed by } \\
\text { a third party (premium, socially- } \\
\text { conscious market and donations). }\end{array}$ \\
\hline Willingness to engage & $\begin{array}{l}\text { EDUCATOR - Make the product/service } \\
\text { attractive to the target beneficiaries } \\
\text { by subsidizing education campaign by } \\
\text { a third party. }\end{array}$ & $\begin{array}{l}\text { SKILLS VALORIZER - Encourage } \\
\text { beneficiaries to enter the labor market } \\
\text { by designing jobs that valorize under- } \\
\text { appreciated skills. }\end{array}$ \\
\hline Access & $\begin{array}{l}\text { CONNECTOR - Make the product/service } \\
\text { accessible to the target beneficiaries } \\
\text { by targeting a third party to pay to } \\
\text { expand the market. }\end{array}$ & $\begin{array}{l}\text { INTEGRATOR - Increase access to the } \\
\text { labor market or to entrepreneurial } \\
\text { activities financed by a third party. }\end{array}$ \\
\hline
\end{tabular}


willingness to engage and lack of access), and to deduce possible solutions. While our above literature review demonstrates that many of these ideal-type business models are already well-documented individually, we suggest that applying the below-proposed analytical grid to delineates such models according to the articulation of their respective business model elements allows for systematic analysis of the opportunities and limitations inherent to each ideal-type. This typology, which is discussed in greater detail below, takes its theoretical cues from the work of Saebi, Foss, and Linder (2019), and from research addressing ways of solving or mitigating economic exclusion. Synthesizing these bodies of literature together with our own analysis of the business model constraints that constitute economic exclusion results in a typology of 12 ideal-type business models for tackling economic exclusion. In the following we will specify the value proposition, value creation and value capture strategy of each ideal-type business model.

\subsection{One-sided value model}

The 'one-sided value model' pictured on the top left of the table designates a social business model that targets beneficiaries for value capture (i.e. beneficiaries are targeted as consumers of essential goods and services). The one-side value model is thus predicated on a single value proposition aimed at beneficiaries as customers. At the same time, beneficiaries are not involved in the value creation process. This is perhaps the simplest business model form, which corresponds to Sanchez and Ricart (2010) isolated model. Using this model to address economic exclusion, social businesses are called on to innovate to attain efficiency gains or to expand market reach in order to achieve financial sustainability.

A pre-eminent constraint for this social business model is beneficiaries' lack of financial resources (low purchasing power). In what we refer to as the 'Affordable Provider' business model, the social business rethinks its value creation process (increasing efficiency) and/or its value proposition (changing the pricing model) to render its product or service affordable. The Affordable Provider business model is exemplified by personal care companies, like L'Oreal, who sell shampoo in small sachets to customers in emerging markets so as to capture value from customers who cannot afford to buy a full bottle at a time (Prahalad and Hart 2002). Yunus, Moingeon, and Lehmann-Ortega (2010) similarly hint at the development of 'good enough' (i.e. high-quality, but still affordable) food products and water services provided by Danone and Veolia, respectively, to low-income customers in developing contexts. By modifying value creation and the value proposition to account for the barriers faced by low-income customers, these firms are able to capture value from target beneficiaries, thereby establishing a financially sustainable business model.

Alternatively, the social business may find that its target beneficiaries are unwilling to pay for existing products and services, not because they cannot afford to, but because these offerings are at odd with their needs. In these cases, social businesses can adopt a 'Designer' business model to carefully design their value propositions to overcome cultural, social, psychological or aesthetic barriers to consumption so as to properly speak to and satisfy the specific needs of beneficiaries. One example of the Designer business model is Odiora, a French social business that creates jewelry and accessories to make hearing aids more attractive to their wearers, thereby overcoming aesthetic and psychological barriers to the adoption of hearing aids. Here, again, value is captured from the 
target beneficiaries (i.e. it is the beneficiaries themselves who purchase the product or service), which renders the business model financially self-sufficient.

In other cases, the barrier facing target beneficiaries is the lack of access to a given product or service rather than the cost of that product or service per se. Lack of access can be caused, for instance, by low market maturity due to potential consumers being geographically dispersed. In response, social businesses can adopt a 'Market Expander' business model, modifying the value proposition so as to appeal to a wider market and achieve financial sustainability. For instance, gluten-free products were once difficult to access because coeliacs constituted a niche market unattractive to traditional businesses. In recent years, however, firms have successfully marketed gluten-free food to a wider market of health-conscious consumers, rendering these products much more profitable and thereby accessible (Singh and Whelan 2011). By modifying the value proposition in this way, social businesses are able to expand the total population of target beneficiaries from whom value is captured, thereby surpassing the threshold of profitability.

\subsection{Two-sided value model}

Social businesses are not always able to attain financial self-sufficiency based on value capture from target beneficiaries, however. If a one-side value model is not applicable, social businesses might adopt a 'two-sided value model', addressing one value proposition to the target beneficiaries, and another value proposition to a third party, from whom value is captured. Neither beneficiaries nor the third party are involved in the value creation process according to this typology.

Where target beneficiaries' economic inclusion is primarily hampered due to their lack of financial resources, a 'Matcher' business model can be adopted, offering an equivalent or premium product or service to the paying third party to subsidize the consumption of the target beneficiaries. One example in this regard would be the Aravind Eye Hospital in India, where patients are charged according to their purchasing power, and revenues from wealthier clients are used to subsidize the treatment of the economically disadvantaged (Santos, Pache, and Birkholz 2015). In this case, the value proposition to both poor and wealthy clients is high-quality medical care. Value is created by the social business and value is captured from a subset of clients (i.e. more affluent consumers). In this model, social businesses achieve financial sustainability if the paying party accepts the higher price necessary to subsidize provision of the product or service to the target beneficiaries. This acceptance might be rooted in, for instance, low competition (e.g. where alternative eye care hospitals are not readily accessible) or their own pro-social motivations (e.g. Toms Shoes customers pay more to cover the cost of a free pair of shoes for a child in need). Social businesses adopting this model must therefore be attentive to factors which may affect paying customers' willingness to accept this higher price.

In other cases, the barrier to economic inclusion is a mismatch between the social business' value proposition and the target beneficiaries' willingness to purchase an essential good or service. In this case, an 'Educator' business model can be used, whereby marketing and education campaigns are rolled out to increase the target beneficiaries' perception of the desirability of the essential product or service. For example, HIV testing can be made more attractive through social marketing campaigns targeting marginalized and at-risk groups by conveying information about the benefits of early detection and 
ease of testing. In this case, the third party funder of the education campaign might be the public health authority, to whom a value proposition of decreased HIV transmissions is offered (Tucker et al. 2012). More generally, we can say that social businesses adopting this model offer one value proposition - of an increased user base - to the third-party payer to fund the education campaign, which increases the efficacy of the second value proposition, aimed at the target beneficiaries. Value is then captured from both the target beneficiaries and the third-party payer to secure the financial sustainability of the business model.

Finally, where the accessibility of the offering is the main barrier preventing economic inclusion, social businesses can engage a 'Connector' business model, targeting one value proposition to a third party so as to enable the provision of the essential product or service to the target beneficiaries. One example here would be CAMI, a social business that provides sports training sessions in hospitals for people battling cancer. Here the barrier is not so much lack of purchasing power, as patients could in principle afford sports training, but rather an issue of coordination due to the health situation beneficiaries find themselves in. The social business thus creates value through the provision of training sessions, thus offering one value proposition to the target beneficiaries (the patients, who get to engage in valued activities otherwise inaccessible to them from hospital) and another one to the third party (the hospital, which has a vital interest in realizing the health benefits associated with physical exercise). Value can be captured from both the target beneficiaries, who may pay fees for the service, and the third-party payer, who may facilitate the service through the provision of space and/or coordination, and may also financially subsidize the sports sessions.

\subsection{Co-production model}

Saebi, Foss, and Linder (2019) define their social-oriented work model as involving a combination of the one-sided value model and the market-oriented work model, whereby social businesses provide an essential product or service to target beneficiaries as consumers, while at the same time providing employment to a subset of this target population. Applying a slightly different understanding of this category according to the key dimensions of the business model elements (value proposition, value creation and value capture), we propose the notion of the 'co-production model' to describe social businesses that articulate a single value proposition targeting beneficiaries in relation to both value creation and value capture, thereby reducing the cost of provision.

In cases where target beneficiaries face barriers to consumption based on their lack of financial resources, social businesses can invoke a 'Do It Yourself (DIY) Enabler' model to attain economic inclusion. An example of a social business adopting the DIY Enabler model is La Louve - a participatory supermarket in Paris, where organic and locally sourced products are made affordable to consumer-members who are involved as producers in the value creation process in monthly three-hour shifts. At La Louve, value creation is effected by the target beneficiaries themselves, thereby establishing an economically sustainable social business model that does not require additional recourse to third parties.

Alternatively, where the principal barrier to economic inclusion is target beneficiaries' willingness to engage, the value proposition can be made more palatable to them through 
a 'Co-creator' business model. Similar to the 'Designer' model mentioned above, this approach requires that the essential product or service be designed to cater to the specific needs of the target population. The distinguishing feature is that in the Co-creator model the design is developed in collaboration with the target beneficiaries themselves. One example of this participatory strategy is the Low Impact Living Affordable Community (Lilac) cohousing project in the UK, which was developed by a group of individuals who wanted to buy homes, but could not find appropriate offerings in the real estate market that met their ecological and social requirements (Chatterton 2013). What is crucially at stake in Lilac is that the value proposition was co-designed by the target beneficiaries over the course of three years of research. Further, value is both created and captured by the beneficiaries, whose needs were otherwise unmet by the housing market.

Finally, if the main barrier to economic exclusion is access, social businesses can engage a 'Facilitator' business model, offering target beneficiaries assistance in achieving goals they themselves have designed and are working towards. For instance, the solidarity lending system introduced by Grameen Bank enables small-scale entrepreneurs in developing economies to access financial products otherwise inaccessible to poor populations (Yunus, Moingeon, and Lehmann-Ortega 2010). Similarly, participative funding platforms, such as Kocoriko, permit social businesses to raise funds through numerous small donations. In both cases, the Facilitator model uses a single value proposition to address target beneficiaries as prospective entrepreneurs, thus capturing value from those entrepreneurs in the form of interest on loans or service fees respectively. These beneficiaries also create value for the social business, as their enterprises realize social value and build up reserves for financing and supporting further entrepreneurial endeavors.

\subsection{Work integration model}

Based on an expansion of Saebi, Foss, and Linder (2019) 'market-oriented work model', we suggest the 'work integration model' to describe social business models that involve target beneficiaries in the value creation process but include a third party for value capture. As a result, social businesses employing this model propose two value propositions - one aimed at the paying third party, and one aimed at the working target beneficiaries. This model is perhaps most widely used by work integration social enterprises (WISEs), which sell goods or services while simultaneously providing training and employment to target beneficiaries (Battilana et al. 2015; Defourny and Nyssens 2017). Our disaggregation of the barriers to economic inclusion - lack of resources, lack of access and unwillingness to engage - reveals an important distinction between, WISEs addressing beneficiaries who lack valued skills, beneficiaries whose skills are undervalued on the labor market, and beneficiaries who are largely excluded or marginalized from the labor market for other reasons, such as immigration or offender status.

In the case of low-skilled beneficiaries, the main barrier to economic inclusion is a lack of resources - in this case essential skills. Social businesses might thus use a 'Job Provider' business model, whereby the value proposition to target beneficiaries is employment and capacity/skill-building through on-the-job training. The social business relying on the Job Provider model captures value through the sale of goods and services. Importantly, market inefficiencies inherent in providing training to low-skilled workers will often prevent the Job Provider model from being financially sustainable without additional 
value capture from other actors. Similar to the Matcher strategy elaborated above, businesses adopting this model may function by compelling more affluent customers to pay above-market prices for pro-social reasons. Alternatively, the social business might gain access to government subsidies or philanthropic funds with the value proposition of ameliorating economic exclusion in exchange for financial support. In this case, social businesses adopting the Job Provider model must be attentive to factors affecting these third parties' willingness to pay. A pertinent example of the Job Provider model is the French social business Atelier Emmaus, which employs homeless and economically marginalized people to collect, repair and sell furniture received as donations. At Atelier Emmaus, target beneficiaries create value while in return gaining employment, skills and various forms of support. In turn, value is captured from those who support the social mission of Atelier Emmaus by donating their old furniture, and from those buying the restored pieces.

Alternatively, in the case where target beneficiaries' skills are not appropriately valued in the traditional labor market, the main barrier to economic inclusion is the lack of willingness to engage. That is, people might be reluctant to sell their labor power if the labor market does not appropriately value their skills. In response, social businesses might pursue a 'Skills Valorizer' model, promoting the particular skills of their target beneficiaries and capitalizing on these skills to establish an economically sustainable business. An example of the Skills Valorizer model can be found in the Danish enterprise, Specialisterne, which places individuals on the autism spectrum in large IT companies, advising these companies on how to design job tasks and work spaces to best utilize and meet the needs of these workers (Spiess-Knafl, Mast, and Jansen 2015). Value at Specialisterne is created by the target beneficiaries who are offered a value proposition of employment designed according to their individual needs and skills. A secondary value proposition targets the firms in which these target beneficiaries are placed. The firms benefit from gaining access to talented employees and receiving advice on how best to support them. Value is captured from the firms in the form of placement fees.

Finally, economic inclusion might be hampered by a lack of access to employment where target beneficiaries are excluded from the labor market for social or political reasons. If this is the case, social businesses can adopt an 'Integrator' business model to provide networking, coaching, mentoring and training activities to target beneficiaries who face such barriers. Although social businesses employing the Integrator model might capture value from target beneficiaries, extra value capture from additional actors might be required to render this model financially sustainable. Thus, the Integrator model often relies on a secondary social value proposition to target third parties, such as sociallyconscious market actors or state agencies. This model has been embraced by helprefugeeswork.org, a Cypriot platform that connects refugees with employers. Here, the value proposed to the target beneficiaries is access to training and employment which will facilitate social integration, while the value proposition to third parties - in this case, state agencies and employers - is refugee integration and access to valuable skills respectively. Value is captured from state agencies in the form of public funds, and from employers in the form of training and on-the-job support. Value is created by target beneficiaries through their skilled labor. This example highlights the potential for work integration business models to involve multiple stakeholders as third parties approached for value 
capture, and also underscores the contingency of such social business models on favorable evaluation of the social purpose by these third parties.

\section{Concluding discussion}

This paper has been motivated by the realization that issue-specific social business model research is largely missing. Focusing on economic exclusion as arguably one of the most crucial grand challenges today has allowed us to take a first step toward identifying promising business models that social businesses can employ to tackle this issue. Inspired by a desire to be relevant and not 'just' rigorous (Gulati 2007), we remain mindful that our typology needs both practical validation and theoretical refinement to be able to deliver on its promise. This said, it is our explicit hope that our typology will be of interest not 'only' to like-minded scholars but also to social businesses by supporting their work in at least two ways. First, by enabling them to compare their current activities with ideal-type business models, thus allowing for analogical, strategic reasoning which may aid the social business in avoiding risky trial-and-error strategies (see Gavetti and Rivkin 2005). Second, by offering such enterprises a more nuanced understanding of how their business model elements can be combined to secure economic inclusion given existing constraints. These insights might in turn facilitate the successful manipulation and adaptation of social business models while reducing the risk of failure due to superficial analogies (ibid.).

Aside from these practical contributions, we would like to emphasize the following theoretical contributions our paper makes. First, our typology of ideal-type social business models provides an opportunity to develop a deeper understanding of the diverse business constraints pertaining to economic exclusion. Based on an extension of the social entrepreneurship typology proposed by Saebi, Foss, and Linder (2019), we have developed a holistic framework for thinking about approaches to alleviating economic exclusion that places greater emphasis on the value proposition, value creation and value capture strategies presupposed by the 12 social business models our typology has identified. Considering configurations of the three business model elements at a relatively high level of abstraction, the 12 social business models of our typology call attention to how adjustment of one business model element requires careful consideration of how the other two are affected. Our typology thus highlights the need to reciprocally adjust the business model elements in accordance with the main constraints at play, so as to ultimately secure the target beneficiaries' economic inclusion.

Second, we identify three distinct barriers to economic inclusion which the business model can be optimized to overcome: lack of financial or internal resources, lack of willingness to engage in consumption or production, and lack of access to essential goods and services. This distinction inter alia highlights that economic exclusion is not merely a question of economic resources, but also closely bound up with social and political factors that limit people's ability to contribute to society, to gain access to economic opportunities and thus to achieve human functioning and flourishing (Sen 2009).

Third, this study contributes to ongoing research on value creation related to extant literature on social business and social entrepreneurship. Recent theorizing in this area has highlighted the trade-off between value capture and value creation (Agafonow 2014, 2015; Certo and Miller 2008; Santos 2012). Santos (2012), for one, suggests that '[s]ocial entrepreneurs are more likely to seek sustainable solutions than to seek sustainable 
advantages' (12), where 'sustainable advantages' are defined at the level of the social business and 'sustainable solutions' are defined at the level of the system. Proposing a shift from the enterprise to the system as the central unit of analysis implies that social businesses might sacrifice some market power (value capture) for the sake of its social mission (value creation). As we have noted above, this proposition contradicts the traditional theory of the firm, which sees value capture (i.e. the maximum appropriation of value created) as the ultimate objective of for-profit entities (Agafonow 2014). This research gives access to the design of social business models and business model elements for social businesses; in particular, it shows how these enterprises can manage the tradeoff between value creation and value capture: the search for profit is attenuated in favor of securing revenues.

One important caveat needs to be mentioned here: the adoption of a social business model perspective necessarily gives priority to business-based responses to social problems, thereby imposing a limited perspective from the outset. The point to note, however, is that economic exclusion can by no means be addressed through business means alone, arguably requiring wider economic, political and social change. Therefore, the approaches identified in our typology must be understood as specific elements in a much broader, multi-pronged response. Indeed, the promotion of social business should not be advanced to the detriment of, for instance, public policy and civil society efforts such as progressive tax reforms, universal basic income, giving circles, etc.

\section{Research agenda}

Given that this paper exclusively engages with social business responses to economic exclusion in theoretical terms, empirical studies are necessary to validate and refine our proposed typology. Furthermore, additional theoretical and empirical analysis could fruitfully explore the boundary conditions and contingency factors of each of the 12 proposed business models, identifying conditions under which such models are likely to be successful.

Due to the complex and wicked nature of grand challenges, unintended consequences and involuntary negative impacts are common (Ferraro, Etzion, and Gehman 2015; Martí 2018). In response, Ferraro, Etzion, and Gehman (2015) propose the concept of 'robust action strategies' to improve social (and environmental) value creation and mitigate involuntary negative impacts. Future research could combine this concept with the ideal-type business models identified in this paper. For instance, Ferraro, Etzion, and Gehman (2015) suggest that some of the risk of unintended consequences can be attenuated by 'participatory forms of architecture' which invite 'fringe' stakeholders to participate in the co-creation of the business model. Future research could investigate the potential inherent in the specific realization of such participation through the three analytically distinct co-production business models for responding to economic exclusion we have identified in this paper - DIY Enabler, Cocreator, Facilitator. Similarly, future research could investigate the extent to which the two-sided value models here identified (Matcher, Educator, Connector) can realize the benefits of 'multivocal inscription', whereby different value interpretations for different audiences can be sustained in a manner that promotes coordination without requiring explicit consensus' (Ferraro, Etzion, and Gehman 2015, 373), since the 
design of the business models we describe requires combining the interests of diverse stakeholders.

A second substantial line of research suggested by the typology here proposed relates to hybridization of ideal-type business models. As noted above, the three core barriers to economic inclusion are often intricately interwoven in practice. Thus, it is appropriate to examine the benefits that might result from a combination of different business models. For instance, it seems fairly uncontroversial to assume that some models are complementary, such as the DIY Enabler and Matcher model (we think here of participatory supermarkets that offer two-tier pricing for more and less affluent customers). Yet other models might be found to be incompatible, generating fundamental contradictions within the business model architecture. Further research is needed to comprehensively account for the mechanisms of such complementarity and contradiction. Similarly, further work may investigate how different types of value (e.g. social inclusion, environmental) can be pursued simultaneously by individual social businesses.

As a first attempt at addressing one of the greatest challenges contemporary economies and societies face - economic exclusion - we are cognizant that our approach is merely a humble, probing beginning. Our typology is exclusively focused on economic exclusion, thus necessarily turning a blind eye toward how economic exclusion is variously entangled with other grand challenges such as, for instance, ecological transition or social inclusion. Further research, both conceptual and empirical, is hence needed to expand and substantiate understanding of how social businesses can leverage business models to increase their beneficiaries' level of economic inclusion. We would thus invite scholars to advance the ideas put forward in this paper.

\section{Notes}

1. These two terms are often used interchangeably, yet a key distinguishing factor is that social business models usually focus on the dual pursuit of economic and social value creation, whereas sustainable business models are characterized by a triple focus, adding environmental value creation to this balancing act.

2. The question of what goods and services count as 'essential' is of course highly contested, and it is not necessary for the purposes of this paper to cash out its meaning in precise terms. As we are informed by the capabilities approach, we defer to the relevant theorists regarding the precise threshold of sufficiency (e.g. Nussbaum 2000; Sen 2009).

3. Addressing beneficiaries as producers instead of 'only' treating them as consumers is conceived by some authors as a more effective, and thus more desirable, mechanism of economic inclusion (Karnani 2007).

\section{Disclosure statement}

No potential conflict of interest was reported by the authors.

\section{ORCID}




\section{References}

Agafonow, A. 2014. "Toward a Positive Theory of Social Entrepreneurship: On Maximizing versus Satisficing Value Capture.” Journal of Business Ethics 125: 709-713. doi:10.1007/s10551-0131948-z.

Agafonow, A. 2015. "Value Creation, Value Capture, and Value Devolution: Where Do Social Enterprises Stand?" Administration \& Society 47: 1038-1060. doi:10.1177/ 0095399714555756.

Amis, J. M., K. A. Munir, and J. Mair. 2017. "Institutions and Economic Inequality.” In The Sage Handbook of Organizational Institutionalism, edited by R. Greenwood, C. Oliver, T. B. Lawrence, and R. E. Meyer, 705-736. Thousand Oaks, CA: Sage.

Austin, J., P. Márquez, E. Reficco, G. Berger, C. Fedato, and R. M. Fischer. 2007. "Building New Business Value Chains with Low-income Sectors in Latin America." In Business Solutions for the Global Poor: Creating Social and Economic Value, edited by K. Rangan, J. Quelch, G. Herrero, B. Barton, 193-206. San Francisco: Jossey-Bass.

Baden-Fuller, C., and V. Mangematin. 2013. "Business Models: A Challenging Agenda: State-ofthe-art and Steps Towards A Research Agenda." Strategic Organization 11: 418-427. doi:10.1177/1476127013510112.

Barth, H., P.-O. Ulvenblad, and P. Ulvenblad. 2017. "Towards A Conceptual Framework of Sustainable Business Model Innovation in Agri-food Sector: A Systematic Literature Review." Sustainability 9 (9): 1620-1635.

Battilana, J., and S. Dorado. 2010. "Building Sustainable Hybrid Organizations: The Case of Commercial Microfinance Organizations." Academic of Management Journal 53 (6): 1419-1440. doi:10.5465/amj.2010.57318391.

Battilana, J., M. Sengul, A.-C. Pache, and J. Model. 2015. "Harnessing Productive Tensions in Hybrid Organizations: The Case of Work Integration Enterprises." Academy of Management Journal 58 (6): 1658-1685. doi:10.5465/amj.2013.0903.

Bloom, P. N. 2009. "Overcoming Consumption Constraints through Social Entrepreneurship." Journal of Public Policy \& Marketing 28: 128-134. doi:10.1509/jppm.28.1.128.

Bocken, N. M. P., S. W. Short, P. Rana, and S. Evans. 2014. "A Literature and Practice Review to Develop Sustainable Business Model Archetypes." Journal of Cleaner Production 65: 42-56. doi:10.1016/j.jclepro.2013.11.039.

Calás, M. B., L. Smircich, and K. A. Bourne. 2009. "Extending the Boundaries: Reframing "Entrepreneurship as Social Change" through Feminist Perspectives." Academy of Management Review 34: 552-569. doi:10.5465/amr.2009.40633597.

Certo, S. T., and T. Miller. 2008. "Social Entrepreneurship: Key Issues and Concepts." Business Horizons 51: 267-271. doi:10.1016/j.bushor.2008.02.009.

Chatterton, P. 2013. “The UK's First Ecological, Affordable Cohousing Community." Interational Journal of Urban and Regional Research 37: 1654-1674. doi:10.1111/1468-2427.12009.

Chaurey, A., P. R. Krithika, D. Palit, S. Rakesh, and B. K. Sovacool. 2012. "New Partnerships and Business Models for Facilitating Energy Access." Energy Policy 47: 48-55. doi:10.1016/j. enpol.2012.03.031.

Cholez, C., P. Trompette, D. Vinck, and T. Reverdy. 2012. "Bridging Access to Electricity through BOP Markets: Between Economic Equations and Political Configurations." Review of Policy Research 29 (6): 713-732. doi:10.1111/ropr.2012.29.issue-6.

Defourny, J., and M. Nyssens. 2017. "Fundamentals for an International Typology of Social Enterprise Models." Voluntas 28 (6): 1-29. doi:10.1007/s11266-017-9884-7.

Dentchev, N., R. Rauter, L. Johannsdottir, Y. Shnihur, M. Rosano, R. Baumgartner, T. Nyberg, X. Tang, and B. van Hoof. 2018. "Embracing the Variety of Sustainable Business Models: A Prolific Field of Research and A Future Research Agenda." Journal of Cleaner Production 194: 695-703. doi:10.1016/j.jclepro.2018.05.156.

Doganova, L., and M. Eyquem-Renault. 2009. "What Do Business Models Do? Innovation Devices in Technology Entrepreneurship." Research Policy 38: 97-108. doi:10.1016/j. respol.2009.08.002. 
Dror, D. M., R. Radermacher, and R. Koren. 2007. "Willingness to Pay for Health Insurance among Rural and Poor Persons: Field Evidence from Seven Micro Health Insurance Units in India." Health Policy 82 (1): 12-27. doi:10.1016/j.healthpol.2006.07.011.

Ferraro, F., D. Etzion, and J. Gehman. 2015. "Tackling Grand Challenges Pragmatically: Robust Action Revisited.” Organization Studies 36 (3): 363-390. doi:10.1177/0170840614563742.

Freeman, E. R., and K. Ginena. 2015. "Rethinking the Purpose of the Corporation: Challenges from Stakeholder Theory." Notizie di Politeia 31 (117): 9-18.

Gassmann, H., K. Frankenberger, and M. Csik. 2014. “The St. Gallen Business Model Navigator.” Working paper. University of St. Gallen: ITEM-HSG.

Gavetti, G., and J. W. Rivkin. 2005. "How Strategists Really Think." Harvard Business Review 83 (4): 54-63.

George, G., J. Howard-Grenville, A. Joshi, and L. Tihanyi. 2016. "Understanding and Tackling Societal Grand Challenges through Management Research.” Academy of Management Journal 59: 1880-1895. doi:10.5465/amj.2016.4007.

Gulati, R. 2007. "Tent Poles, Tribalism, and Boundary Spanning: The Rigor-relevance Debate in Management Research.” Academy of Management Journal 50 (4): 775-782. doi:10.5465/ amj.2007.26279170.

Hlady-Rispal, M., and V. Servantie. 2018. "Deconstructing the Way in Which Value Is Created in the Context of Social Entrepreneurship." International Journal of Management Reviews 20 (1): 62-80. doi:10.1111/ijmr.2018.20.issue-1.

Hodge, I., J. Dunn, S. Monk, and M. Fitzgerald. 2002. "Barriers to Participation in Residual Rural Labour Markets." Work, Employment and Society 16 (3): 457-476. doi:10.1177/ 095001702762217434.

Karnani, A. 2007. "The Mirage of Marketing to the Bottom of the Pyramid: How the Private Sector Can Help Alleviate Poverty." California Management Review 49 (4): 90-111. doi:10.2307/ 41166407.

Le Ber, M. J., and O. Branzei. 2010. "Towards a Critical Theory of Value Creation in Cross-sector Partnerships.” Organization 17 (5): 599-629. doi:10.1177/1350508410372621.

Margolis, J. D., and J. P. Walsh. 2003. "Misery Loves Companies: Rethinking Social Initiatives by Business." Administrative Science Quarterly 48: 268-305. doi:10.2307/3556659.

Marquez, P., E. Reficco, and G. Berger. 2010. Socially Inclusive Business: Engaging the Poor through Market Initiatives in Iberoamerica. Cambridge, MA: Harvard University Press.

Martí, I. 2018. “Transformational Business Models, Grand Challenges, and Social Impact.” Journal of Business Ethics 152 (4): 965-976. doi:10.1007/s10551-018-3824-3.

McDonald, R. E. 2007. “An Investigation of Innovation in Non-profit Organizations: The Role of Organizational Mission." Nonprofit and Voluntary Sector Quarterly 36 (2): 256-281. doi:10.1177/0899764006295996.

McKee-Ryan, F., Z. Song, C. R. Wanberg, and A. J. Kinicki. 2005. "Psychological and Physical Well-being during Unemployment: A Meta-analytic Study." Journal of Applied Psychology 90 (1): 53-76. doi:10.1037/0021-9010.90.1.53.

Newman, A., S. Schwarz, and D. Ahlstrom. 2017. "Microfinance and Entrepreneurship: An Introduction." International Small Business Journal 35 (7): 787-792. doi:10.1177/ 0266242617719314.

Nussbaum, M. C. 2000. Women and Human Development: The Capabilities Approach. Cambrige, UK: Cambridge University Press.

Osterwalder, A. 2004. The Business Model Ontology - A Proposition in A Design Science Approach. Switzerland: University of Lausanne.

Prahalad, C. K., and A. Hammond. 2002. "Serving the World's Poor, Profitably." Harvard Business Review 80 (9): 48-58.

Prahalad, C. K., and S. L. Hart. 2002. "The Fortune at the Bottom of the Pyramid." Strategy \& Business 26: 54-67.

Saebi, T., N. J. Foss, and S. Linder. 2019. "Social Entrepreneurship Research: Past Achievements and Future Promises.” Journal of Management 45 (1): 70-95. doi:10.1177/0149206318793196. 
Sanchez, P., and J. E. Ricart. 2010. "Business Model Innovation and Sources of Value Creation in Low-income Markets.” European Management Review 7: 138-154. doi:10.1057/emr.2010.16.

Santos, F., A.-C. Pache, and C. Birkholz. 2015. "Making Hybrids Work: Aligning Business Models and Organizational Design for Social Enterprises." California Management Review 57 (3): 36-58. doi:10.1525/cmr.2015.57.3.36.

Santos, F. M. 2012. “A Positive Theory of Social Entrepreneurship.” Journal of Business Ethics 111: 335-351. doi:10.1007/s10551-012-1413-4.

Scherer, A. G., and G. Palazzo. 2011. "The New Political Role of Business in a Globalized world-A Review of a New Perspective on CSR and Its Implications for the Firm, Governance, and Democracy." Journal of Management Studies 48 (4): 899-931. doi:10.1111/j.14676486.2010.00950.x.

Sen, A. 2009. The Idea of Justice. Cambridge, MA: Harvard University Press.

Singh, J., and K. Whelan. 2011. "Limited Availability and Higher Cost of Gluten-free Foods." Journal of Human Nutrition and Dietetics 24 (5): 479-486. doi:10.1111/jhn.2011.24.issue-5.

Sinkovics, N., R. R. Sikovics, and M. Yamin. 2014. "The Role of Social Value Creation in Business Model Formulation at the Bottom of the Pyramid: Implications for MNEs?" International Business Review 23 (4): 692-707. doi:10.1016/j.ibusrev.2013.12.004.

Sirkeci, I., N. Acik, B. Saunders, and A. Přívara. 2018. "Barriers for Highly Qualified A8 Immigrants in the UK Labour Market." Work, Employment and Society 32 (5): 906-924. doi:10.1177/0950017017726912.

Spicer, A., M. Alvesson, and D. Kärreman. 2009. "Critical Performativity: The Unfinished Business of Critical Management Studies.” Human Relations 62 (4): 537-560. doi:10.1177/ 0018726708101984.

Spiess-Knafl, W., C. Mast, and S. A. Jansen. 2015. "On the Nature of Social Business Model Innovation." Social Business 5 (2): 113-130. doi:10.1362/204440815X14373846978624.

Spieth, P., S. Schneider, T. Clauß, and D. Eichenberg. 2018. "Value Drivers of Social Businesses: A Business Model Perspective." Long Range Planning 52 (3): 427-444. doi:10.1016/j. lrp.2018.04.004.

Stephan, U., M. Patterson, C. Kelly, and J. Mair. 2016. "Organizations Driving Positive Social Change: A Review and an Integrative Framework of Change Processes." Journal of Management 42 (5): 1250-1281. doi:10.1177/0149206316633268.

Steyaert, S. 2011. "Entrepreneurship as In(ter)vention: Reconsidering the Conceptual Politics of Method in Entrepreneurship Studies." Entrepreneurship \& Regional Development: An International Journal 23 (1-2): 77-88. doi:10.1080/08985626.2011.540416.

Sundaram, R., U. Hoerning, N. de Andrade Falcão, N. Millan, C. Tokman, and M. Zini. 2015. Portraits of Labor Market Exclusion. Washington, DC: World Bank.

Teece, D. J. 2010. "Business Models, Business Strategy and Innovation.” Long Range Planning 43 (2-3): 172-194. doi:10.1016/j.lrp.2009.07.003.

Tsui, A. S. 2019. “Guidepost: Responsible Research and Responsible Leadership Studies.” Academy of Management Discoveries. doi:10.5465/amd.2019.0244.

Tucker, J. D., K. A. Fenton, R. Peckham, and R. W. Peeling. 2012. "Social Entrepreneurship for Sexual Health (SESH): A New Approach for Enabling Delivery of Sexual Health Services among Most-at-risk Populations.” PLoS Medicine 9 (7): e1001266. doi:10.1371/journal.pmed.1001266.

UNDP (United Nations Development Programme). 2011. "Beyond Transition, Towards Inclusive Societies." http://hdr.undp.org/en/content/beyond-transition

Veldman, J., and H. Willmott. 2013. "What Is the Corporation and Why Does It Matter?" M@n@gement 16 (5): 605-620. doi:10.3917/mana.165.0605.

Viswanathan, M., and S. Sridharan. 2012. "Product Development for the BoP: Insights on Concept and Prototype Development from University-Based Student Projects in India." Journal of Product Innovation Management 29 (1): 52-69. doi:10.1111/jpim.2011.29.issue-1.

Weidner, L. K., J. A. Rosa, and M. Viswanathan. 2010. "Marketing to Subsistence Consumers: Lessons from Practice." Journal of Business Research 63 (6): 559-569. doi:10.1016/j. jbusres.2009.02.022. 
Wheatley, J. 2007. "The Economic Status of National Minorities in Europe: A Four-case Study." Journal of Ethnopolitics and Minority Issues in Europe 6 (1): 1-35.

Whelan, C., and B. Maitre. 2005. Economic Exclusion, Social Exclusion and Social Integration in an Enlarged European Union. Dublin: Economic Social Research Institute.

Wilson, F., and J. E. Post. 2013. "Business Models for People, Planet (\& Profits): Exploring the Phenomena of Social Business, a Market-based Approach to Social Value Creation." Small Business Economics 40 (3): 715-737. doi:10.1007/s11187-011-9401-0.

Wirtz, B. W., A. Pistoia, S. Ullrich, and V. Göttel. 2016. "Business Models: Origin, Development and Further Research Perspectives." Long Range Planning 49 (1): 36-54. doi:10.1016/j. lrp.2015.04.001.

Wrigley, N., D. Warm, B. Margetts, and A. Whelan. 2002. "Assessing the Impact of Improved Retail Access on Diet in a 'Food Desert': A Preliminary Report." Urban Studies 39 (11): 2061-2082. doi:10.1080/0042098022000011362.

Yunus, M., B. Moingeon, and L. Lehmann-Ortega. 2010. "Building Social Business Models: Lessons from the Grameen Experience." Long Range Planning 43 (2-3): 308-325. doi:10.1016/ j.lrp.2009.12.005.

Zott, C., and R. Amit. 2007. "Business Model Design and the Performance of Entrepreneurial Firms.” Organization Science 18 (2): 181-199. doi:10.1287/orsc.1060.0232.

Zott, C., and R. Amit. 2010. "Designing Your Future Business Model: An Activity System Perspective." Long Range Planning 43: 216-226. doi:10.1016/j.lrp.2009.07.004.

Zott, C., R. Amit, and L. Massa. 2011. "The Business Model: Recent Developments and Future Research." Journal of Management 37 (4): 1019-1042. doi:10.1177/0149206311406265. 